\title{
Determinants of High and Continuous Inflation Rates in the United Arab Emirates: A Managerial Point of View
}

\author{
Mahmoud Kamal Abouraia \\ Hamdan Bin Mohammed Smart University \\ PO Box 71400, Dubai Academic City, Dubai, UAE
}

Tel: 971-4424-1111Ｅ-mail: m_kamal100@ hotmail.com

Received: July 20, 2016 Accepted: August 3, 2016 Published: September, 2016

doi:10.5296/bms.v7i2.10067 URL: http://dx.doi.org/10.5296/bms.v7i2.10067

\begin{abstract}
Inflation has become serious and argumentative problems for most developed countries. The impact of these concerns derived from various sources, each of which may bring about diverse effects on economic activity in general. Among different countries, United Arab Emirates as one of oil-dependent country has an extremely particular involvement as far as inflation. Economy of UAE has experienced occasions of high (2006-2008) and low (2010-2011) regimes of double digit inflation for more than decades. With the price precariousness, a consistent and tenacious increment has been found to influence financial development, way of life similarly the value of the currency, which thusly impacts the country's conversion standard. The purpose of this paper endeavors to clarify the determinants that subsidize extensively to inflation in the UAE. The methodology utilized as a part of this examination depends on interpretive strategy which derived from perception and through evaluation of literatures relating to the subject matter. The investigation was finished by analyzing, examining and selecting of data systematically and objectively in order to gather collated information. The findings uncovered inflationary pressure influences UAE organizations is through the principle parts of consumer price data. In addition, this paper additionally expected to have a wide understanding to the implementation of management strategies, including contractionary fiscal and monetary approaches to diminish the money supply and ultimately the spending in the country.
\end{abstract}

Keywords: Inflation rate, United Arab Emirates 


\section{Introduction}

UAE is an alliance of seven governments which contained Ajman, Abu Dhabi, Dubai, Ras al-Khaimah, Fujairah, Umm al-Quwain and Sharjah under the protection and administration of British government in 1971. Amid that time, their monetary movement was overwhelmed by farming, fishing and pearling which gave job and wage to the masses (Hurriez, 2013). After the discovery and export of oil, a tremendous change in the economy has been seen definitely and apparently. Presently, UAE's economy moves from a survival state to a cutting edge high-wage nation. It has a populace of 9.45 million including 12 percent Emirates and 88 percent expatriates. In a recent report by Ali (2016), other nationals are India 27.15 percent, Pakistan 12.53 percent, Bangladesh 7.31 percent, Philippines 5.49 percent, Iran 5.22 percent, Egypt 4.18 percent, Nepal and Sri Lanka 3.13 percent, China and Jordan 2.09 percent, Afghanistan and Palestine 1.57 percent, and UK with 1.25 percent. Additionally, UAE is the middle for global management business with solid worldwide exchange status and immense state-claimed speculation reserve that put resources into genuine and bud getary resources (Shayah, 2015). It is additionally the most aggressive and diversified in the Gulf Cooperation Council, with a total of USD570 billion in Gross Domestic Product (GDP) proportionate to AED2.1 trillion in 2014 (APEDA, 2016). For example, they made modern cities like Dubai that equipped with inventive innovation and facility, electricity and utilities. Research indicates that Dubai as one of constituent Emirates is the most crowded city developing into a worldwide city and global aeronautics center (Srinivasan, 2014).

Financial analysts trusted that this monetary development can be credited into four strategic components. To begin with, Al-Khouri (2012) indicates that enormous state interest in social and physical framework. It also enhanced monetary action in general. Next, is a steady global economy situation which is described by low inflation rates, employment, state strategies, and semi-fixed conversion scale. After that, is the accessibility of capital and lack of boundaries on capital development in conjunction with an exorbitant level of unrestricted access that opened the entryway for astounding development in outside exchange. According to the study by Furchtgott-Roth (2007), this notion gives an organization more impetus to grow which prompts more occupations. Lastly, is the accessibility of generally modest work from surrounding Arab nations and the Indian subcontinent (Elhiraika and Hamed, 2006). Although the nation still in existence and amazingly dependent on natural resources, distribution of crude oil and natural gas outside the country still play an important role in the economy. With widely unstable and by large reducing oil costs and state's income, the nation has applied remarkable endeavors went for accomplishing monetary broadening. UAE economy as a part of worldwide economy has paid a high cost to dispose the inflation rate and the global financial crisis which brought profound subsidence. Al-Jundi (2012) indicates that those sorts of emergency clearly bombarded the UAE economy too. Therefore, this extremely incremented a few issues; for case, the criticalness of the premises must alter after some time, changes of costs for the fundamental things devoured by households and even transportations. The impartial of this research is to distinguish the critical components that provide outstandingly to the high and consistent inflation rate. Additionally, investigate the 
strategies to combat the inflationary pressures in the economy of the United Arab Emirates.

\section{Purposes of the Study}

a. To explain the determinants of inflationary pressures that contribute to the inflation

b. To have a wide understanding to the implementation of management strategies

c. To determine appropriate tools to combat inflation rates

\section{Review of the Literature}

Since decades, inflation has become serious and argumentative problems for most developing countries around the globe (Espinoza et al., 2010). However, the effect of these concerns in the development and advancement of the economy cannot be over-accentuated. Though inflation rate is not new in the international studies and in the UAE financial history, the dynamic inflation has been a reason for extraordinary concern to numerous. Further, preserving a low and securing inflation rate is among of the difficulties in the global economic situation facing by the government of UAE. This unpretentious component is recognized to as inflation and characterized by professional market analysts as an incessant rise in costs. According to the study by Dwivedi (2010), inflation is essentially clarified as a considerable and relentless ascent in the wide spectrum of price status across a consistent timeframe. For instance, it is from 2003 to 2008 (Farnham, 2010). An upsurge in the overall price level believes that the estimation of goods and services increases faster than the value of cash supply. There is an assortment of measurements utilized by government and organizations to get the aggregate value list of goods and services and even in setting monetary strategy. The most prevalently utilized total value measurement and highly imperative are the accompanying methodologies; (i) Gross National Product; (ii) Producer Price Index and (iii) Consumer Price Index. The processes of the inflation rate are probably parallel similarly, despite the fact that not to the same degree. Then again, contrasts can consider due to the divergent quantity of items. Researchers affirmed that none of them rather interestingly best measure of inflation, yet voluminous empirical studies discovered opposite (Bamidele and Joseph, 2014). Other academic scholars agreed that CPI and PPI have seen as immediate measures of inflation (Ndidi, 2013); Fatukasi, 2006). For various authors they believed that the best direct measure of inflation rate in the accepted media is unquestionably the one in light of the consumer price index.

Another researcher opined that consumer price index is the slightest effective methodology used to gauge the normal change in costs of a representative basket of customer products and services over the economy (Essien, 2002). It is essentially utilized by expert financial analysts and statisticians as a monetary indicator and as an asset of adjusting current-period information for inflation. The inflation rates are computed as weighted midpoints of the rates and as often as possible distribute on month to month, quarterly and yearly basis. Case in point, if CPI is three percent, this implies by and large, the price of items and services purchased is three percent higher than a year prior. At the end of the day, shoppers would need to spend through three percent more to purchase the same items and services which 
have been purchased a year ago. Also, there are a few drawbacks of the consumer price index as a degree of price quantity: (i) it doesn't imitate merchandize and services purchased by organizations or management, for example, apparatus; (ii) it doesn't mirror the adjustment in the nature of merchandize which may have happened additional time; (iii) deviations in the cost of identical merchandize are not wedged; (iv) consumer price index basket for the most part does not change regularly. Regardless of these deficiencies, Umaru and Zubairu (2012) agreed that consumer price index is still the most broadly utilized management guideline of the broad-spectrum of price quantity. This is on account of it is utilized for automatic adjustment drives for some pay and compensation workers, including employees in the government.

Business analysts and monetary counselors have been perceived a long time that inflation results from supported increment in the broad value level within the resources and wealth of a nation. Nonetheless, this increment can be brought by various elements. As indicated to Keynesian schools of thought there are two noteworthy factors of inflation as shown in figure 1. Godin and Lane (2013) stated that the first factor is the "demand-pull inflation" which experienced from the 1960s to the mid-1970s in the United States of America. This occurrence is otherwise called the "Phillips Curve" inflation. This factor results from an underlying increment in total interest. Bayo's research (2011) indicates that the output gap may happen from various elements, for example, an abundance of accessible supply, an expansion in government purchases and an increment in exports. All these will clearly prompt an ascent in value. Case in point, envision that there were 100 clients who all needed to purchase smart TVs however just 50 were on stock. In this setting, just 50 percent of the clients are going to wind up purchasing the item. As a result of this, everybody will pay a tremendous sum just to have this item until limited assets last. Likewise, the organization can utilized the current circumstance to change the cost of popularity item until they discover a point that clients won't have the capacity to pay any longer.

According to Thomas (2006), the next factor is known as "cost-push inflation", "commodity inflation" or "supply shocks inflation" which happens from an underlying increment in costs where at hand no reasonable options. There are various fundamental basis of expanded costs such as rising labor costs (an expansion in the cash remuneration degree); component costs (e.g. an expansion in the cash cost of crude materials), and higher indirect taxes forced by the government administration (ascend in the standard rate of VAT). For example, the reason for "cost-push inflation" is the point at which the restraining infrastructure force of huge professional organizations empowers them to raise costs. Every time the businesses raise costs, the average cost for basic items ascended. Specialists and employees then request high amount in salaries to compensate for the decrease in their way of life and accordingly give the businesses a reason to strengthen the price status another time (Javed et al., 2010). Despite the fact that the divergences in inflation recognized may seem straightforward, the beginning stage of changes in value level witnessed in the genuine economy that delivers products and services are frequently more multifarious. In a dynamic economy like UAE can be especially difficult to isolate a solitary reason for an adjustment in the value level. In any 


\section{Macrothink}

case, recognizing what inflation is and in what conditions may bring would be an incredible stun.
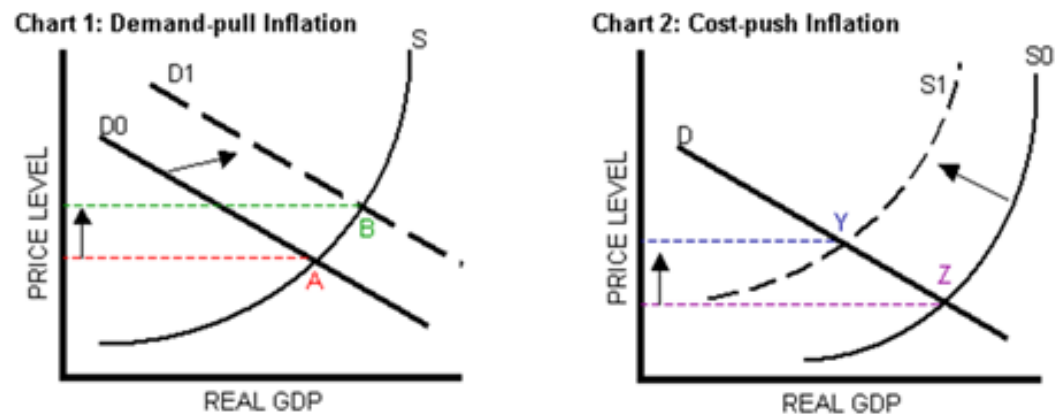

Figure 1. Major types of inflation

\section{Inflationary Trend in UAE}

As discovered in figure 2 below, it is observable that UAE as a rich nation for the most part because of its humble populace base and tremendous oil assets which has been attacking with the significant challenges of price precariousness, an instance of the general value level; measured by inflation soaring around a single digit and double digit figure. It shows the unfavorable variation of the inflation rates over a persistent timeframe, with the unequaled most astounding inflation rate recorded in 2008 (12.30 percent), whose high rising started in 1990 (2.40 percent), which is normally of the exploitation of oil, known for extreme going through not coordinated with expanded efficiency and the business design does not reflect the output structure. Unlike countries like Brazil, Peru and Argentina were unquestionably encounter high rates of inflation to more than three digit inflation without remaining long in the moderate extent (Carlson, 2013), the chart reveals that UAE has never experienced 3-digit inflation, however has essentially been experienced with double digit inflation for more than two decades. Furthermore, the diagram uncovered strength of price level around great rate; 0.67 percent and 1.1 percent somewhere around 2012 and 2013.

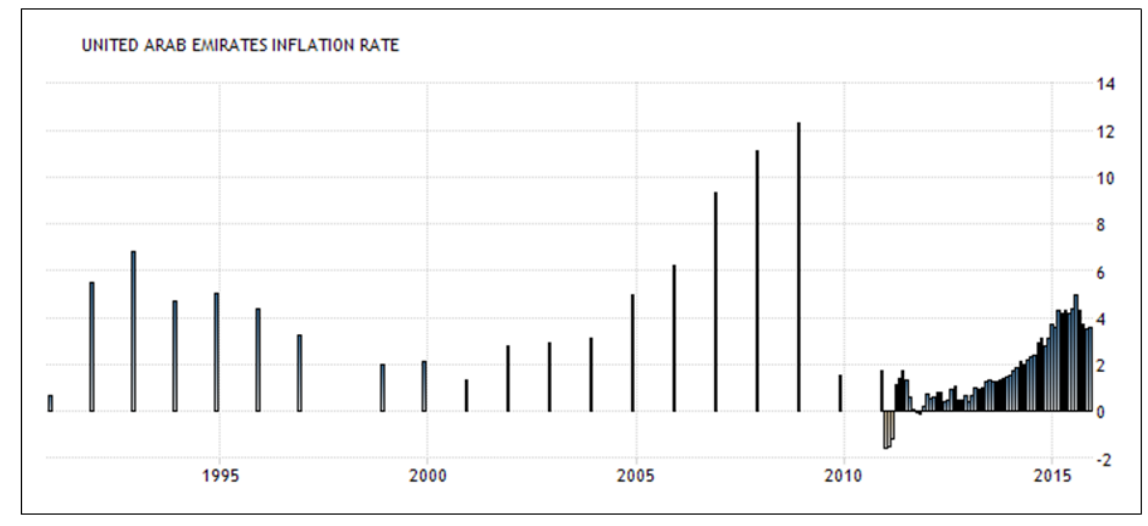

Figure 2. Diagram showing inflationary trend in UAE (1990-2015)

Source: $\underline{w w w . t r a d i n g e c o n o m i c s . c o m}|\underline{w w w . s t a t i s t a . c o m}|$ NBS, United Arab Emirates 


\section{Research Methodology}

The objective of exploratory research is to accumulate data to give understanding on what is occurring. Saunders et al. (2009) affirmed that along these lines exploratory study is utilized to discover and depict general patterns and to comprehend connections in certain circumstance. The kind of exploration utilized for the current research depends on interpretive examination technique. It concentrates on logically revealing those significance "meaning-making practices", while demonstrating how those procedures arrange to create detectable results. The philosophical establishing of interpretive examination depends on specialists' inclinations and style of gathering auxiliary information which got from contextual analyses, corporate reports, and distributed excellent writings and statistics of official universal production. The practicality of using optional information for examination is turning out to be more ubiquitous due to its pre-set up level of legitimacy and reliability which need not be reconsidered. It likewise gives all encompassing choice for authors and professionals to make their investigation more thorough and to convey their discoveries more powerful particularly in a constrained time and assets.

\section{Research Findings}

The business industry has distinguished that inflationary pressure can impact economic resilience in the UAE and undoubtedly, these notions are consistent with other economic studies. According to National Bureau of Statistics, UAE inflation rate rose to record 3.60 percent for the last parts of 2015 contrasted with the same time of 2014 . This is due to an increase in the prices of furnishings, household equipment and routine household maintenance group in addition to depreciation of US dollar exchange rate. The findings revealed that an inflationary pressure influences UAE organizations is through the principles of segments of consumer price data which has a base of 100 as of 2007. These variables are housing and utilities, food and beverages, and transportations and the relative significance of these elements developed to the consumer basket. At this crucial juncture in UAE financial development, the main component that has been identified by the researchers is housing and utilities. UAE continues to dominate as the most attractive destination in the GCC for expatriates. 63 percent of the professionals surveyed picked UAE as the place they would be most likely to move to. The country likewise appreciates the most noteworthy degree of consistency in the district with 88 percent of expatriates already dwelling in the country expressing a desire to remain there (Gulf Talent, 2016). Be that as it may, expatriates persistent in facing critical difficulties because of the increasing average cost for basic items and costs identified with bringing up youngsters.

The consumer price index in the United Arab Emirates expanded basically determined by expense of housing and utilities. Agreeing to the Department of Economic Development, the heaviness of rent in the UAE takes more than 40 percent of the consumer basket which was the most noteworthy component that impact inflation (DED, 2009). For expatriates relocating to UAE and living in freehold (owned) and non-freehold (rented) housing ought to need to set-up family unit utilities, for example, electric and water utility association with the 
authority. Ferris-Lay (2011) mentioned that for non-freehold property, the lodging concerns charged through occupants' month to month service bills for 5\% of yearly lease while freehold property proprietors pay $5 \%$ of the yearly rental quality as controlled by Real Estate Regulatory Agency rental list. These amounts are partitioned by twelve months and every month invoiced in portions. Also, the occupant will need to give a maintenance deposit normally five percent of the aggregate rent amount to ensure support of premises toward the end of tenure contract. This is a refundable deposit as indicated to Article 20 of the law controlling the relationship amongst proprietors and occupants (Law no. 26 of 2007).

The second component recognized by the financial scientists was food and beverages. UAE vigorously reliant on imported food for human consumption and animal feed which are assessed to represent more than 75 percent of the food supply, somewhat as an after effect of the greatest height of hindrances in delivering harvests in this district. According to the report of Australian Government (2008), the constrained agricultural food item of UAE creates with the nation. The following products are poultry and eggs, fresh tomatoes, dairy products, some vegetables, and seafood. With these commodities, it does not shock anyone that UAE positioned world's third greatest spenders on food and beverages. In actuality the yearly per capita purchaser consumption of UAE was US\$21,823 in 2012, with food and beverages representing US\$3,111 or 14.2 percent of that aggregate (Agriculture and Agri-Food Canada, 2014). The food and beverage sector beginning to extend their business over the next five years to take care of the demand. In a report, around 19,000 extra food and beverage outlets in the UAE are relied upon to proceed over the 2014-2019 period (Scott, 2016). To some degree, this expanded will bring competition that makes the business remain robust and globally competitive. In addition, the purchaser group is continually developing to incorporate a more youthful era which is more cognizant about their eating regimens, wellness levels and general wellbeing. Truth be told, by most recent Global Health \& Wellness survey by Nielsen, eighty-three percent will pay an exceptional for nourishments with sound traits, sixty-three percent are attempting to get thinner and fifty-five percent accept that they are above a weight. Clearly, the research by Chakra (2015) anticipated that the wellbeing emergency in the UAE could be an inspiration for item organizations to upgrade and make even adjust their commodities to the customer's slant for more beneficial nourishment and beverages.

Pursuing this further, the research recognized transportation as another factor which affects the inflation rate of developed and developing countries. Transportation is a vital requirement for specialization allowing production and distribution of goods and services to take place at different places. Furthermore, transportation is a non-separable part of any society because the goods and services will be available for consumption. A change in transportation adds to the monetary sound ness of people, organizations, and whole countries by encouraging the stream of business and giving livelihood prospects (Council of Supply Chain Management Professionals et al., 2014; Mathew, 2014). In spite of the vehicle supportability a major issue, Global Enabling Trade Report 2012 proclaimed that United Arab Emirates has been positioned $1^{\text {st }}$ locally and $11^{\text {th }}$ worldwide regarding the accessibility and nature of transport 
framework. In a late report, it was avowed that transportation and logistics infrastructure is a key premise for monetary advancement and development and additionally broadening. The transport infrastructure is on upward way with incomes of USD8, 100 million in 2012, ascending at a yearly normal rate of approximately nine percent (AHK, 2013). The rate could be because of new period of economic transition which is depicted by public-private organizations that are assuming key parts in framework advancement. Based on case study of Avaya (2011) there are USD $\$ 100$ billion (Dh 367 billion) worth of base ventures were either effectively in progress or planned for the near future. Apart from the real interest of government in energy industry, a detailed proposal contain another air terminal, different ventures will likewise go some way towards meeting the groundwork requirements of an extremely expanding and urbanized populace (UAE Yearbook, 2007). The remaining factors added to the inflation rate of UAE are as seen in table 1.

Table 1. Remaining factors in the inflation rate of UAE

\begin{tabular}{|l|l|}
\hline Factors & Percentage \\
\hline Textiles, clothing and footwear & 7 \\
\hline Communications & 6.9 \\
\hline Miscellaneous goods and services & 5 \\
\hline Restaurants and hotels & 4.3 \\
\hline Furniture and household goods & 4.2 \\
\hline Education & 4 \\
\hline Recreation and culture & 3 \\
\hline Beverages and tobacco & 2 \\
\hline Medical care & 1 \\
\hline
\end{tabular}

\section{Discussion}

Generally, there are a number of policy options available to policy makers to combat inflation rates, including fiscal, monetary, exchange rate, and structural policies. Effective policies for controlling inflation need to focus on appropriate tools that could reduce the side effects of an increase in consumer prices from a wide range of sources. For instance, if the main cause of inflation stems from demand-pull sources, then appropriate policy measures must be crafted to directly address those sources. Otherwise, tackling demand-pull inflation with policies that have direct bearing on cost-push inflation may not be very effective; rather, it will even compound the inflationary pressures. A mixture of policies is, however, required when the 
causes of inflation are eclectic in nature (Salisu and Bousrih, 2013).

It is generally perceived that fiscal arrangement has genuine consequences for the UAE economy over the short period. Despite what might be expected, most bud getary specialists and business analysts acknowledge the possibility that the long run impacts of fiscal arrangement descend completely on costs (Sweiden, 2009). Zaidi (2005) asserted that its component has genuine ramifications for monetary improvement of the nation, as it decides how and where assets are to be designated in the distinctive economic sectors. Therefore, the essential reported goal of national banks is to accomplish and practical measures of monetary development alongside short and constant percentages of inflation (Ibarra and Trupkin, 2016; Malik, 2007). In UAE, it is basically focused at keeping up the quality of being steady or unfailing in price and maintains a pegged conversion scale of AED3.67 to the US dollar. This traded rate regime has been grasped following 1980 with vast accomplishment brought about by the huge foreign reserves the nation holds and essential for the private sector's certainty. As indicated by a late yearly report is sued by the national bank and because of the amassed asset report of business banks, Al-Jundi (2012) saw substantial credit facilities given to the private sector achieved Dhs 730 billion in 2008 and somewhat dropped in the next year. In any case, this approach has different drawbacks. For example, if the US dollar ascends towards different monetary forms, the UAE dirham will likewise fortify in opposition to different monetary exchanges. As a result, this will prompt a collapse in importation prices, subsequently provide to slope downwards the inflation, however in the meantime the intensity of the exportation of non- liquefiable substances will be debilitated. Furthermore, if the dollar deteriorates this would likewise debilitate the UAE dirham towards alternate monetary forms, and the costs of importations will raise in making inflationary weights, particularly since the majority of importations originate from the comfort zone of other territory (Elhiraika and Hamed, 2006).

An additional strategy element that assumed a dynamic part in building up the UAE economy and its huge effect are well postulated in the macroeconomic theory. The income configuration in the United Arab Emirates has been ruled by petroleum revenues produced from international petrol reservoir amassed from previous oil revenue. Another numinous sound with the UAE is that there is no "income tax" or "consumption tax" in the United Arab Emirates. Along these lines, financial presentation of the nation is to a great extent subject to petrol costs. The extreme oil cost in the late 1970s to mid-1980s has brought about excesses. Since mid-1980s, with deterioration of petroleum costs, developing populace, expanding structural price level and improving compensation charge, the UAE economic growth has encountered spending deficiencies in the majority of the years. The spending shortage has ended up basic in category. To the extent financial development is tense, the impact of spending shortfall relies on upon how it is supported. The United Arab Emirates illustrating the international resources and remodeling profits created by these external resources subsidized the spending deficiency. Along these lines, the nation spending deficiency has no deleterious impacts, for example, eliminate private sector spending. Anyway, in perspective of accessible data, this technique for financing the deficiencies is impractical throughout the 
day. Rolling out improvements in authority spending and assessments is also known as "fiscal policy". The approach ought to move the center from capitalizing to systemic change that involves augmenting the non-liquefiable income base, motivational structure, legitimizing authority's expenses and reassessing sponsorships, and transferring an enterprise of public ventures to private sector. Elhiraika and Hamed (2006) asserts that financial change may antagonistically influence non-liquefiable movement in the limited term, yet it is important for accomplishing reasonable development after a long period of time. Thus, government ought to cut its spending or/and increment changes in an attempt to prevent inflation from expanding. An excessive in a public budget is a strategy to control the broad price level. The UAE government ought to force value added taxes (VAT) in addition to income taxes that would actuate the adequacy of financial strategy to impact the entire monetary exercises in the nation (Al-Jundi, 2012).

\section{Conclusion and Recommendations}

The researcher believed that inflation has an adverse effect on standard of living for the fact that individual need to shell out progressively for the personal and local services. Be that as it may, if the salary did not go up at the same expense and inflation, the standard of living decreasing regardless of the ways that individual are making more effort. In like manner, inflation has no room to influence everything uniformly, subsequently various things can work while something else might be potentially lose regard. With this notion, it creates monetary arrangement more strenuous and extra unpleasant response. When individuals discovered towards inflation, they might proceed in a specific direction at the moment instead of later, for the fact that things will simply cost to a great extent. On the other hand, this individual spending prepares the economy better, driving towards additional inflationary pressures.

The inflation procedure has changed fundamentally in the most recent period. In addition, numerous arrangements of meetings have been considered with a specific end goal to maintain strategic distance from an ascending development of this. Appropriately, the Central Bank of UAE has organized a remarkable consistency in the economic markets the same as an inflation fighter. Moreover, most influential worldwide rivalry restraints the pricing power, regardless of rising operation and production costs. Besides, innovation has impeded the development rate of work material costs obtained while delivering a division of creation. Notwithstanding today, online network engaged well its part in providing different pricing power towards the general population through empowering them to bounce now over the source of what they need instead of managing through retailers. However, this new arrangement framework is to a great degree accommodating towards the UAE economy. In result, the quality of being steady or unfailing in price allotted organizations to be optimistic in preparing it better for the benefit of them to create indication later. The study revealed that a proposal for building organizational change technique or approaches are blatant.

Initially, the national bank ought to enact the devices of fiscal strategy to have the capacity to alter the amount of cash supply as per the level of potential Gross Domestic Product. Next, 
the monetary service ought to initiate the apparatuses of monetary approach to empower to change public budget plan as indicated by the level of potential Gross Domestic Product. And then, the UAE dirham exchange scale ought to be re-assessed and the altered connection with the US dollar should be changed into a wide base. After that, the legislature should put more resources into an expansive apartment complex for public workers or servants and urge the private sector to invest in housing for the middle layer of society. That will build the supply of housing units. Lastly, to wrap things up is the government should extend public transportation to take out the expense of transport for the work and materials. The consequences of this research and the suggestions displayed above will be useful to the government of the United Arab Emirates and investors or shareholders required as they deliberate the tasks in the future.

\section{Acknowledgement}

The interpretations and definitions conveyed in this research are those of the financial analysts and academic researchers. This study do not characterize to those of the organization to which academic researchers have involved. The academic researchers might want to recognize the helpful remarks expected from unidentified reviewers. However continual inaccuracies and deletions, if any, are those of the academic researchers.

\section{References}

Agriculture and Agri-Food Canada (2014). Market overview: United Arab Emirates. Ottawa, Canada.

AHK (2007). Transport and logistics in the UAE. [Online] Available: http://vae.ahk.de/fileadmin/ahk_vae/Members/Committees/Transport__Logistics_Sectorial_ Overview.pdf

Al-Jundi, S. (2012). Inflation in United Arab Emirates. Economic Horizons, 33(121), 9-36. Federation of UAE Chambers of Commerce \& Industry.

Al-Khoudari, A. M. (2012). eGovernment Strategies: The Case of the United Arab Emirates. European Journal of ePractice, 17, 126-150. [Online] Available: www.epracticejournal.eu

APEDA - Agricultural and Processed food products Export Development Authority (2016). E-APEX: Showcasing India food products, pp. 1-27. Ministry of Commerce \& Industry: Government of India. [Online] Available: http://apeda.gov.in/apedawebsite/

Australian Government (2008). Food to the United Arab Emirates. Australia: Australian Trade Commission-Austrade 2008. [Online] Available: https://www.austrade.gov.au/Artic leDocuments/.../Annual-Report-200809-Full.pdf

Avaya (2011). How a $21^{\text {st }}$ century contact center serves the public and improved customer satisfaction by 50 percent: Case study, pp. 1-4. [Online] Available: www.avaya.com

Bamidele, T. B., \& Joseph, A. I. (2014). Inflation and money supply in Nigeria. Journal of 
Business and Organizational Development, 6(1), 29-44.

Bayo, F. (2011). Determinants of inflation in Nigeria: An empirical analysis. International Journal of Humanities and Social Science, 1(18), 262-271. [Online] Available: www.ijhssnet.com

Carlson, M. (2013). Determinants of hyperinflation: Case studies from Latin America (Economics Senior Thesis, The College of New Jersey, New Jersey, United States). [Online] Available: http://business.pages.tcnj.edu/files/2013/07/Carlson-thesis-2013.pdf

Chakra, J. (2015). Huge appetite for UAE's food and beverage sector: All the ingredients remain present for start-ups to get into the act. [Online] Available: http://gulfnews.com/business/

Council of Supply Chain Management Professionals, Goldsby, T. J., Iyengar, D. \& Rao, S. (2014). The definitive guide to transportation: Principles, strategies, and decisions for the effective flow of goods and services. Upper Saddle River, New Jersey: Pearson Education, Inc.

Dwivedi (2010). Macroeconomics (3rd ed). Noida, UP, India: Tata McGraw-Hill Education.

Elhiraika, A. B., \& Hamed, A. H. (2006). Explaining growth in an oil-dependent economy: The case of the United Arab Emirates. In Jeffrey B. Nugent, M. Hashem Pesaran (ed.), Explaining growth in the Middle East (Contributions to economic analysis, 278). Emerald Group Publishing Limited, pp. 359-383.

Espinoza, R., Leon, H., \& Prasad, A. (2010). Estimating the inflation-growth nexus: A smooth transition model. IMF Working Paper $N^{\circ} 10 / 76$, Middle East and Central Asia Department. Washington D.C., US A: International Monetary Fund (IMF).

Essien, E. A. (2005). Exchange Rate Pass-Through to Inflation in Nigeria. West African Journal of Monetary and Economic Integration, 5(1), 89-103. [Online] Available: https://www.econbiz.de

Farnham, P. G. (2010). Economics for managers (2nd ed). Pearson Education International.

Ferris-Lay, C. (2011). All Dubai expats to pay housing fees by June (17 October). [Online] Available:

http://www.arabianbusiness.com/all-dubai-expats-pay-housing-fees-by-june-425660.html

Furchtgott-Ruth, D. (2007). Adjusting to free trade. [Online] Available: http://www.american.com/archive/2007/november-11-07/adjusting_to_free_trade.

Godin, B., \& Lane, J. P. (2013). Pushes and pulls: The hi(story) of the demand pull model of innovation, Working Paper No. 13, Project on the Intellectual History of Innovation, Montréal : INRS. 39 p. Science, Technology and Human Values, 38(5), 621-54.

Hurriez, S. H. (2013). Folklore and Folklife in the United Arab Emirates: Culture and 
Civilization in the Middle East. New Fetter Lane, London: Routledge Curzon.

Ibarra, R., \& Trupkin, D. R. (2016). Reexamining the relationship between inflation and growth: Do institutions matter in developing countries? Economic Modelling, 52, 332-351. http://dx.doi.org/10.1016/j.econmod.2015.09.011

Javed, Z. H., Farooq, M. \& Akram, S. (2010). Cost-push shocks and inflation: An empirical analysis from the economy of Pakistan. Journal of Economics and International Finance, 2(12), 308-312. [Online] Available: http://www.academicjournals.org/JEIF

Malik, W.S. (2007). Monetary Policy Objective in Pakistan: An Empirical Investigation. PIDE Working Papers, Islamabad, pp. 1-25. [Online] Available: http://pide.org.pk/pdf/Working\%20Paper/WorkingPaper-35.pdf

Mathew, T. V. (2014). Role of transportation in society: Lecture notes in traffic engineering and management, $\quad$ pp. 1-10. Anline] Available: https://www.civil.iitb.ac.in/tvm/1111_npte1/102_TptnRole/plain/plain.html

Ndidi, D. E. (2013). Determinants of inflation in Nigeria (1970-2010). The Business and Management Review, 3(2), 106-114. [Online] Available: www.abrmr.com

Salisu, M., \& Bousrih, L. (2013). Inflation in the GCC Countries: Old challenge in a new context. Gulf One Investment Bank Research Bulletin, 1-15. [Online] Available: http://www.gulf1bank.com/

Saunders, M., Lewis, P., \& Thornhill, A. (2009). Research methods for Business Students, 5th edition. Pearson Education, Italy.

Scott, A. (2016). Eating is the new shopping as UAE malls grow fat on new restaurant tenants. [Online] Available: http://www.thenational.ae/business/retail

Shayah, M. H. (2015). Economic Diversification by Boosting Non-Oil Exports: Case of UAE. Journal of Economics, Business and Management, 3(7), 735-738. http ://dx.doi.org/10.7763/JOEBM.2015.V3.276

Srinivasan, I. (30 December, 2014). It's official: Dubai international is world's busiest airport. The National. [Online] Available: http://www.thenational.ae/business/aviation/its-official-dubai-international-is-worlds-busiestairport

Sweidan, O. D. (2009). Asymmetric central bank's preference and inflation rate in Jordan. Studies in Economics and Finance, 26(4), 232-245. http ://dx.doi.org/10.1108/10867370910995690

Thomas, P. (2006). Does the US have a handle of inflation? Street Insight.

Umaru, A., \& Zubairu, A. A. (2012). Effect of Inflation on the Growth and Development of the Nigerian Economy: An Empirical Analysis. International Journal of Business and Social 


\section{Macrothink Institute ${ }^{\mathrm{TM}}$}

Science, $\quad 3(10)$,

Business Management and Strategy ISSN 2157-6068 2016, Vol. 7, No. 2

www.ijbssnet.com/journals/Vol_3_No_10_Special_Issue_May_2012/19.pdf

Zaidi, S. A. (2005). Issues in Pakistan Economy (2nd ed). Oxford University Press Korangi Industrial Area, Karachi, Pakistan, pp. 283-307.

\section{Copy right Disclaimer}

Copyright for this article is retained by the author(s), with first publication rights granted to the journal.

This is an open-access article distributed under the terms and conditions of the Creative Commons Attribution license (http://creativecommons.org/licenses/by/3.0/). 